\title{
A metáfora do amor: A posição do analista perante o (des)encontro no encontro amoroso
}

\section{The love metaphor: The analyst's role in the face of (mis)matches on love matches}

\section{La metáfora del amor: La posición del analista frente al (des)encuentro en el encuentro amoroso}

\author{
Simone Ravizzini* \\ Niterói, Rio de Janeiro, Brasil
}

\section{Paulo Eduardo Viana Vidal**}

Universidade Federal Fluminense - UFF, Niterói, Rio de Janeiro, Brasil

\begin{abstract}
RESUMO
O presente trabalho propõe circunscrever um delineamento possível para pensarmos o amor, a transferência e a posição do analista diante da limitação caracterizada em cada enlace amoroso. Tal limitação é problematizada pela psicanálise lacaniana como um vazio estrutural que, devido à relação com a linguagem, resta no encontro entre os sujeitos. A trilha para esse caminho entreabre-se guiada pela concepção, proposta por Lacan, de que o falante é um ser sem essência, que precisa passar pelo significante para se representar. Neste movimento, algo é cifrado circunscrevendo, concomitantemente, um vazio inextirpável em seu advento. Almeja-se então pensar como o amor, amparado pela escuta analítica, pode lidar com esta falta, encarnada como um desencontro por aqueles que amam, sem comparecer apenas como uma enganação que a escamoteia. Assim, esse artigo bordeja uma diferente resposta possível para a emergência de um caminho inédito para o amor. Com esse intuito, perpassam-se textos lacanianos sobre amor e transferência, textos freudianos sobre a técnica analítica e passagens da literatura.
\end{abstract}

Palavras-chave: psicanálise, amor, enganação, transferência, posição do analista.

\begin{abstract}
The present work aims at circumscribing a possible outlining when considering love, transference and the analyst's role facing the distinct limitations on each and every love engagement. The aforementioned limitation has been problematized by Lacanian psychoanalysis as a structural void which lies on the encounter of the subjects due to their relation with language. This path unravels guided by the conception, proposed by Lacan, that the speaker is an essence-lacking being, who needs to go through the significance in order to represent themselves. While experiencing this movement, something is concurrently ciphered, circumscribing an inextirpable void at its arrival. It is sought to think how love, sustained by
\end{abstract}


analytical listening, may deal with that void, incarnated on a mismatch lived by those who love, avoiding presenting itself as some deceiving pilfering. Thus, this article seeks a distinctive possible answer to an emerging original path for love. Along this motif, spans Lacanian texts regarding love and displacement, Freudian texts with reference to analytical technique and literature excerpts.

Keywords: psychoanalysis, love, deception, displacement, the analyst's role.

\begin{abstract}
RESUMEN
El presente trabajo se propone trazar un dibujo posible para pensar el amor, la transferencia y la posición del analista frente a la limitación caracterizada en cada enlace amoroso. Tal limitación es problematizada por el psicoanálisis lacaniano como un vacío estructural que surge en el encuentro entre dos sujetos debido a su relación con el lenguaje. El sendero para este camino se entreabre guiado por la noción, propuesta por Lacan, de que el hablante es un ser sin esencia, que necesita pasar por el significante para representarse. En este movimiento, algo es cifrado circunscribiendo, al mismo tiempo, un vacío inextirpable en su acontecimiento. Se anhela entonces pensar como el amor, amparado por la escucha analítica, puede lidiar con esta falta, encarnada como un desencuentro por aquellos que se aman, sin aparecer apenas como un engaño que la esconde. Así pues, este artículo contorna una posible respuesta diferente para la emergencia de un camino inédito para el amor. Con esta intención, se recorren textos lacanianos sobre el amor y transferencia, textos freudianos sobre la técnica analítica y pasajes de la literatura.
\end{abstract}

Palabras-clave: psicoanálisis, amor, engaño, transferencia, posición del analista.

Porque eu fazia do amor um cálculo errado: Pensava que, somando as compreensões, eu amava. Não sabia que, somando as incompreensões, é que se ama verdadeiramente. (Clarice Lispector)

Quando Lacan (1992/1960-61) inicia seu seminário sobre a Transferência, o faz demarcando a necessidade de percebermos a disparidade que irremediavelmente ocorre e se mantém em qualquer enlace estabelecido entre os falantes. Tal pontuação não é ingênua e inaugura o pensamento de que, em toda relação amorosa que se instaura, resiste algo incompleto. É como se nos advertisse que, na troca entre amante e amado, reside inexoravelmente um não acoplamento entre os parceiros, deixando em seu rastro um vazio impreenchível. Considerando isso, com este estudo, visamos circunscrever um delineamento possível para pensarmos o amor, a transferência e a posição do analista diante da limitação característica de cada enlace amoroso. Entendemos que ao analista cabe sustentar esse vazio que nos concerne, não nos iludindo com a possibilidade de sobrepujar o muro constituído pela linguagem, para que com essa 
posição possa viabilizar o outro lidar com o que é entendido como um desencontro presente no encontro de amor.

Esse desajuste é mesmo irremediável quando se trata de seres submetidos à linguagem, posto que, desde o início de sua implicação no mundo, o falante precisa apelar para um céu de letrinhas a fim de constituir seu desejo. Essas estrelas são seu guia e sua estrutura, selando um distanciamento perene no trato com qualquer objeto. A trilha para esse caminho se entreabre conduzida pela concepção lacaniana de que o ser falante é um ser sem essência. Ele insiste em escapulir, tendo sua existência confinada ao exílio na medida em que, ao tentar se representar, precisa passar pelo significante. Nesse movimento, algo é cifrado circunscrevendo, concomitantemente, um vazio inextirpável em seu advento. Assim, no caso da transferência, a disparidade e o distanciamento não são apenas percebidos, mas também, necessariamente, acentuados pela posição do analista, uma posição que não comporta a mesma resposta daquele que é amado.

Através dessa demarcação, Lacan (1992/1960-61) procura destituir a suposição de alguns clínicos, herdeiros do trabalho de Anna Freud, de que entre os seres falantes a intersubjetividade seria plenamente concretizável, a comutabilidade poderia ser exercida em sua integralidade. Essa pretensa conjectura embasava algumas terapias na época de seu ensino, norteando-as pela via de que seria interessante ao analista se colocar na posição do outro, em um caminho de mão dupla, como se houvesse possibilidade de comunicação irrestrita entre os seres humanos. Tal possibilidade funcionaria como um termômetro que conduziria o percurso desse tipo de escuta na medida em que, sob esta perspectiva, não existiriam limites entre eu e o outro.

Logo de começo no tracejo do fenômeno do amor transferencial Lacan (1992/1960-61) derruba essa perspectiva sublinhando que só existe amor a três, ou seja, a linguagem opera implacavelmente entre amante e amado e traz consigo um muro intransponível. Seguindo tal viés, o significante se pronuncia entre sujeito e objeto, instituindo o fio condutor que guiará o ser falante ao longo de toda sua vida. Ele apresenta as formas possíveis de implicação para o sujeito. Isso comparece em qualquer aliança que se estabeleça, seja no caso do amor de transferência, seja no amor da vida cotidiana.

Lacan (1992/1960-61) nos alerta que nada relativo aos seres de fala pode existir sem o uso do significante. E, portanto, ao lidarmos com a questão do objeto de amor em psicanálise devemos ter sempre em mente que ele é também perpassado pela linguagem. Seu advento é especificamente definido pela eficácia da operação significante como tal, na medida em que. se o homem fala, para falar ele precisa ser capturado e implicado em um discurso preexistente, de forma que 0 homem somente se constitui e se relaciona com o outro na posição de uma eterna presa do simbólico. Nesse advento, haverá sempre um 
resto impossível de se representar. Diante disso, Lacan (1992/196061) pode dizer que oferecemos ilusoriamente ao outro algo que não possuímos: a completude.

\section{O olhar sobre o amor de transferência}

Retomando nosso olhar para o amor de transferência, perguntas importantes despontam em textos psicanalíticos e nos servem como guia de investigação. Uma delas transfigura-se quando procuramos entender como um dispositivo, que é artificialmente combinado, propicia o advento do amor, sem que o analista faça qualquer esforço nessa direção. Outra consiste em problematizar se devemos caracterizar esse amor como um amor verdadeiro.

Para melhor definir a relação entre amor e amor de transferência, Lacan (1986/1953-54) se apropria do texto freudiano intitulado Observações sobre o amor transferencial (Freud, 1969/1915), portador de novas recomendações sobre a técnica em psicanálise. Tal texto comparece como pedra angular na possibilidade de entrelaçamento dos dois amores, permitindo a articulação entre ambos. Nesse texto, nomeia-se a transferência como amor, dandoIhe caráter verídico, equivalente a qualquer outro amor em nosso cotidiano.

Nas observações sobre o amor transferencial, Freud não hesita em chamar a transferência pelo nome de amor. Freud elude tão pouco o fenômeno amoroso, passional, no sentido mais concreto, que chega a dizer que não há entre a transferência e - que chamamos na vida o amor, nenhuma distinção verdadeiramente essencial. A estrutura desse fenômeno artificial, que é a da transferência e a do fenômeno espontâneo que chamamos amor, e muito precisamente o amor paixão, são no plano psíquico equivalentes (...) A transferência é o amor (Lacan, 1986/1953-54, p. 108).

A partir dessa ancoragem, possibilita-se uma correlação entre o amor de transferência e o amor da vida cotidiana. Ambos teriam a mesma estrutura, embora não possam ser respondidos de modo equivalente, pois a escuta do analista deve propiciar outro caminho para o amor, um caminho que direciona a análise até seu termo final: 0 concernimento da falta que nos constitui, ou seja, de nossa castração. Assim, o analista não pode se deixar seduzir pela proposta do amor, onde dois conseguiriam se unir em um. Ele precisa sustentar uma posição pelo meio da qual o sujeito possa identificar, durante esse processo, o significante faltante que the concerne. "O que está realmente em causa na relação analítica é que alguém possa 
se isolar com um outro para aprender o que the falta. E o que the falta, ele vai aprender amando" (Lacan, 1992/1960-61, p. 23).

Por isso, no referido texto de 1915 onde tal articulação ocorre, Freud levanta a importante questão quanto à posição de um analista frente ao amor que advém de um paciente. Ele compreende, desde então, que não seria plausível a um analista lidar com esse sentimento da mesma maneira que um amado, posto que o que se visa no trabalho de uma análise pode sucumbir diante do inebriamento promovido pela paixão.

Assim, todo o texto freudiano sobre o amor de transferência é conduzido almejando refletir acerca do lugar de onde deve responder o analista a esse sentimento emergente. Ali, Freud não apenas confirma o amor de transferência como um amor verdadeiro, como também sublinha a necessidade do analista operar a partir dessa inédita posição que é inaugurada com a psicanálise.

\section{O manejo da transferência: para onde se dirige o amor?}

Freud (1969/1915) apresenta diferentes soluções diante do amor que advém do decorrer de uma análise. Por um lado, pode-se desenvolver um sentimento entre ambos, analista e analisando, que acarrete em uma união outra que não o laço analítico. Muitos são os exemplos advindos do cinema americano e entranhados no imaginário popular, no qual o foco de uma análise consiste em levar adiante a relação amorosa tal como um leigo a conceberia. Podemos vê-los representados através de filmes como Um método perigoso (2011) ou Augustine (2012). Há algo de mítico nesta relação que, como nos diz Lacan (1992/1960-61), também se passa entre quatro paredes e de forma privada entre dois parceiros. Essa postura é devidamente contraindicada por Freud.

Então, deve-se ter cautela diante desse sentimento. Mesmo que um analista não corresponda à paixão oriunda do paciente, a pergunta quanto à sua posição deve ser constante. Isso porque, se ele não puder se posicionar adequadamente perante o lugar que o paciente Ihe endereça, poderá acarretar na dissolução do trabalho de análise, na medida em que essa paixão poderá advir como uma resistência. Freud (1969/1915) nos diz que qualquer retribuição a essa afeição, na tentativa de apaziguar o paciente de seus anseios, estaria apenas alimentando o desejo de impedir a continuidade do trabalho analítico. Em outras palavras, estaríamos endossando a utilização do amor pela resistência, colocando-o a seu serviço, pois "tudo que interfere com a continuação do tratamento é caracterizado como resistência" (Freud, 1969/1915, p. 211).

Portanto, é preciso saber como manejar esse amor para tomá-lo a nosso favor na guerra contra a neurose. 
Instigar a paciente a suprimir, renunciar ou sublimar suas pulsões, no momento em que ela admitiu sua transferência erótica, seria, não uma maneira analítica de lidar com eles, mas uma maneira insensata. Seria exatamente como se, após invocar um espírito dos infernos, mediante astutos encantamentos, devêssemos mandá-los de volta para baixo, sem Ihe haver feito uma única pergunta. Ter-se-ia trazido o recalcado à consciência, apenas para recalcá-lo mais uma vez, num susto (Freud, 1969/1915, p. 213).

Para que o manejo possa ocorrer não se pode estar iludido quanto à origem do amor emergente em uma análise, visto esse ser somente causado pela situação analítica e não por qualquer outro atributo advindo da pessoa do analista. Não se trata de uma conquista, tal como vemos na vida corriqueira, muito menos de um mérito aferido pela competência do analista através de seus dotes intelectuais. Freud é enfático quanto a isso!

Em texto antecedente, Recomendações aos médicos que exercem a psicanálise, Freud (1976/1912) já procurava sublinhar a diferente posição que deve ocupar um analista, nos alertando quanto ao perigo dele ter em mente qualquer ambição terapêutica que não seja o desejo de escutar o que advém da fala do sujeito. Ele chega a dizer que precisamos funcionar como um aparelho, uma extensão telefônica, que sirva apenas como suporte da fala que nos é direcionada. Qualquer outra expectativa só serve para desvirtuar o caminho de uma análise.

Lacan (1992/1960-61) acentua que um analista deve ser ignorante quanto ao que the é apresentado. Ele precisa se deixar surpreender com o que comparece através do discurso de cada paciente. Nesse discurso, a verdade surge da equivocação, ou seja, ela emerge onde a palavra falta, onde o ato é falho, onde o erro diz mais sobre o sujeito do que sua própria intenção de dizer. Ali, nas entrelinhas, algo aponta para um saber de outra ordem, o qual Freud denominou saber inconsciente.

Quanto ao seu desejo, o analista deve não ser para que possa se posicionar. Só há eficácia em sua posição quando ele se oferece perante o que é intransmissível. Podemos dizer que não sendo ele pode ser tomado pelo paciente em sua série psíquica que dele faz seu uso singular.

Para que um analista possa ter aquilo que falta ao outro, é preciso que ele tenha a nesciencia enquanto nesciencia. É preciso que ele esteja sob o modo de ter, que ele não seja. Sem dúvida, ele está sempre para além de tudo o que o sujeito sabe, sem poder dizer isso a ele. Só pode Ihe fazer signo, ser 
aquilo que representa alguma coisa para alguém (Lacan, 1992/1960-61, p. 232).

De tal modo, o analista faz signo dizendo sim a essa apropriação necessária ao analisando para que entre em análise. Ele faz semblante daquele que tem algo a dar: um saber sobre o sintoma, mas o que ele preserva é a falta de um significante capaz de responder à demanda que lhe é endereçada. A essa demanda o analista diz não. Por isso, não se trata de um conhecimento cumulativo por parte do analista, posto que é precisamente ao que escapa ao discurso que precisamos nos ater. A experiência analítica se realiza uma a uma, de forma que o saber de um analista não pode ser constituído pelo acúmulo de suas experiências.

Compactuando com o olhar freudiano, em Lógicas da vida amorosa, Miller retoma o valor da singularidade na escuta de um analista.

A experiência em nosso campo responde à Lógica do não todo. Significa que só tem este analisante, e aquele e aquele outro, quer dizer, uma série que não faz uma soma. A partir do que se passou não se pode saber, dali em diante, o que se passará. Não só qual é a diferença que acontecerá entre duas curas, como inclusive em uma mesma cura. Isto constitui a abertura da experiência analítica (...) não importa qual seja o número de elementos, em psicanálise, o etcetera é irredutível (Miller, 2009 , p. 6).

Portanto, não há regras a priori através das quais um analista possa se balizar para conduzir uma análise. Essa é a grande dificuldade para quem principia como analista, pois não há amparo em uma técnica exterior ao que ocorre em uma análise, algo que forneça suporte neste percurso. Aí reside importante diferença para outras terapias que se utilizam da fala. O único standard que nos é apresentado na psicanálise é que uma análise se inicia e que terá um fim. No seu porvir, nenhuma previsibilidade é coerente com 0 trabalho que decorrerá.

Por isso Freud (1976/1913), em Sobre o início do tratamento, se utiliza da comparação quanto à partida de xadrez. Nesse caso, poderse-ia ambicionar uma conjectura das jogadas que deveriam advir, mas o jogo que se jogará será sempre singular e desenvolvido somente naquela partida. Concomitantemente, cada análise se apresenta de forma ímpar e é por esse motivo que haver conduzido uma análise não servirá em nada, num certo nível, para empreender qualquer outra. E não só não serve de nada como é preciso se esquecer de uma para conduzir a próxima. Essa é a recomendação freudiana. Portanto, quanto ao amor que surge no estabelecimento 
de uma análise, não há uma técnica de antemão para que possamos lidar com ele.

Mas qual seria então o lugar comum entre a transferência e o amor, posto que esse necessariamente ocorrerá em uma análise? Precisamente 0 ato de fala. Decorre deste ato a explicação do surgimento automático do amor na análise. Falar a alguém implica que simbolicamente se transfere algo ao outro.

Na sua essência, a transferência eficaz de que se trata é simplesmente $o$ ato da palavra. Cada vez que um homem fala ao outro de maneira autêntica e plena, há no sentido próprio, transferência simbólica - alguma coisa se passa que muda a natureza dos dois seres em presença (Lacan, 1992/1960-61, p. 130).

Assim, no seminário sobre a Transferência, vemos a sustentação lacaniana desta questão introduzida por Freud: o que um analista deveria ser para responder ao amor? Com esse intuito, Lacan se apropria do vigoroso texto de Platão (1983), o Banquete, visando problematizar a estruturação amorosa e a questão transferencial. Temos em cena, nesse texto, a posição do amante, a do amado e, pela releitura lacaniana, a do analista. $O$ Banquete fornece referência a toda tradição que é a nossa no que diz respeito à estrutura do amor. Mesmo sendo um texto antigo permanece como o melhor subsídio para falarmos sobre como se constitui a relação amorosa ainda nos dias contemporâneos, porque consegue sublinhar precisamente os elementos que incidem no advento amoroso.

O que ocorre no Banquete? Alguns importantes filósofos se reúnem em um jantar na casa de Agatão, belo poeta trágico, onde propõem não se embriagarem para poderem melhor discutir sobre o que seria o amor. O assunto é, para eles, de suma importância. A seu ver, é preciso ter sabedoria para que se possa lidar com o amor. No debate, muitos acreditam que o amor seria um Deus, entretanto, outros Ihe darão diferente estatuto, inclusive Sócrates.

Um dos tipos de amor grego se caracteriza como amor entre cidadãos, ou seja, entre homens. Nesse caso, não se trata de um amor que vise constituição familiar. Ele é, mais propriamente falando, um amor entre belos rapazes. Além disso, é um amor entremeado pela questão com o desejo. Assim, em sua equação temos alguns componentes bem delineados. De um lado, comparece o érôménos, continuamente representado pelo mais jovem e imberbe, e enaltecido por sua beleza equivalente à perfeição da estátua de um Deus grego. De outro, se apresenta o érastès, o amante, sempre de barba e atitude ativa de sedução, para a qual utiliza diversos meios.

Esse amor não era um amor qualquer, possuía regras próprias de funcionamento a serem seguidas. Podemos analisar essas regras 
através das pinturas das ânforas, tão representativas da sociedade grega. O amante é caracterizado com o pênis ereto, o amado nunca. Inclusive, 0 tamanho do pênis desse último se apresenta expressamente diminuído. As normas dos contatos sexuais proibiam qualquer espécie de penetração, visto ser inaceitável para um cidadão grego. Seu exercício poderia implicar na perda da cidadania. Nesse caso de amor entre os gregos, o amante se designa sempre como o ativo da relação. Algo lhe falta e ele almeja alcançar isso através da corte ao amado, geralmente o Belo. É importante sublinhar o lugar que Lacan dá ao amante enquanto o desejante no decorrer do Seminário. Podemos evidenciar também o lugar do amado como aquele que nunca está em posição de demonstrar seu desejo. Ele é o desejado. Por isso, enquanto acompanhamos o Seminário sobre a Transferência, temos dificuldade em distinguir as dimensões de amor e de desejo que ali se apresentam. Elas comparecem entrelaçadas a ponto de entendermos que, nessa aproximação, Lacan pretende mostrar que o analisando precisa passar da posição daquele que demanda amor para aquele que deseja, a partir do encontro com a falta que lhe concerne no decorrer de uma análise.

Assim, dentre os diversos discursos apresentados por Platão (1983), consideramos pertinente trazer como exemplo o discurso de Fedro, pinçado por Lacan no capítulo $A$ Metáfora do amor. Com ele, Lacan (1992/1960-61) vai retomar a intervenção de Fedro, recortando a possibilidade de passagem da posição de amado a amante (érastés a érôménos) como a operação constitutiva da metáfora do amor. A seu ver, embora o movimento ocorra, entre os dois termos "não há nenhuma coincidência. O que falta a um não é o que existe, escondido, no outro. Aí está todo o problema do amor" (Lacan, $1992 / 160-61$, p. 46). Trata-se do fato de que todo aquele que o vivencia é capturado por essa hiância.

A pergunta que introduz Fedro é a que tipo de ato amoroso os deuses dariam maior valor. Dessa forma, ele propõe uma comparação entre distintos atos amorosos. Um dos exemplos fornecidos por Fedro é o caso de Alceste e de seu marido. Ele é condenado à morte e ela se oferece para substituí-lo na punição. Embora fosse ele quem deveria morrer, ela se sacrifica morrendo em seu lugar, por amor. Outro exemplo nos é oferecido através do caso de Aquiles e Pátroclo. Aquiles, o amado, vê seu amante morrer pelas mãos de Heitor. De tal modo, ele vai procurar enfrentar o assassino de Pátroclo em busca de vingança. Sua tarefa era certeira em seu destino de morte, posto ser Heitor mais hábil e preparado para a luta do que ele próprio. Ainda assim, apesar desta certeza, Aquiles não se detém em enfrentar Heitor, o algoz de seu amante.

De acordo com Fedro, esse segundo ato de amor é superior ao primeiro no nível ético, e por isso muito mais apreciado pelos deuses. 
Ele acredita que o agir de Aquiles é mais virtuoso e nobre na medida em que é preciso que ele mude de posição, de amado para amante, demonstrando seu desejo. No caso de Alceste, ela já funcionava todo o tempo como a amante da relação. Para ela, não foi preciso qualquer mudança de posição.

E nessa passagem de uma posição a outra que Lacan vai se situar para falar da constituição da metáfora do amor, propondo que quando ela opera se produz uma substituição do érômènos pelo érastés. Nesse ponto Lacan oferece seu próprio mito do amor:

Esta mão que se estende para o fruto, para a rosa, para a tocha que se inflama de repente, seu gesto de pegar, de atrair, de atiçar é estreitamente solidário à maturação do fruto, à beleza da flor, ao flamejar da tocha. Mas quando nesse movimento de pegar, de atrair, de atiçar, a mão foi longe o bastante em direção ao objeto, se do fruto, da flor, da tocha, sai uma mão que se estende ao encontro da mão que é a de vocês, e neste momento é a sua mão que se detém fixa na plenitude fechada do fruto, aberta em flor, na explosão de uma mão em chamas - então, o que aí se produz é o amor (Lacan, 1992/1960-61, p. 59).

Assim, com o mito se presentifica uma mão que se movimenta na direção de um objeto. Entretanto, é precisamente nesse momento no qual ela poderia captá-lo que ele se modifica - há aí uma transformação metafórica. Justamente nesse instante ele deixa sua condição de objeto, posto que o que sai desse lugar é uma mão que se estende em retribuição. Porém, a estrutura de que se trata não é de simetria no retorno. Essa mão, que se desdobra em sua direção fixa aquela que estava na posição ativa de tomar o objeto, situando-a também como um objeto. O acaso propicia que um enlace se estabeleça nessa mudança de posição. Lacan (1992/1960-61) vai chamar a esse encontro de milagre, na medida em que acontece apesar do almejado nunca ser realmente encontrado.

Portanto, nesse encontro submetido ao acaso não se trata de complementaridade, de uma fusão entre sujeito e objeto. Se isso fosse possível não poderíamos falar de uma operação metafórica, de substituição através do signo. A mão não encontra jamais o que procura. Quando se direciona à flor, ao fruto ou ao fogo, o que vem em seu retorno é outra mão, isto é, o desejo do outro. E é esse desejo que permite fixar a mão sobre o objeto. Podemos traçar um paralelo do amante quando busca algo no amado, mas que se depara, em contrapartida, com o desejo desse.

Dessa forma, o mito apresentado por Lacan (1992/1960-61) no Seminário sobre a Transferência caracteriza o que é peculiar no 
enlace amoroso: um encontro no desencontro. Seguindo os passos de Lacan, Dafunchio (2011, p. 55) acrescenta que

Esse encontro no desencontro, próprio do amor, leva Lacan a defini-lo como amar é dar o que não se tem a alguém que não o é. Trata-se de uma dupla dimensão da falta ou de um redobramento da falta. Decorre disso que ao amar é dar o que não se tem, Lacan agrega a alguém que não o é.

Exemplo interessante, fornecido também por Dafunchio (2011), comparece através da figura do baile de máscaras, na tentativa de ilustrar a dupla face da falta inerente ao jogo do amor. Um casal se encontra no baile e cada um deles está convencido de que o outro é seu amor. Ele tem certeza de que ela é essa que o encanta, enquanto ela não duvida ser ele aquele de quem tanto gosta. Dançam juntos a noite toda, trocam juras de amor, mas quando termina o baile e caem as máscaras, ele não era ele e ela tampouco era quem ele imaginava que fosse. Cada um deles acreditava que estava com alguém que na verdade era outro. Essa imagem demonstra adequadamente o encontro e o desencontro no enlace amoroso, o dar o que não se tem a alguém que não o é.

Outro exemplo curioso quanto a esse ponto ilusório produzido pelo amor pode ser tomado da literatura. Está contido na comédia do século XIX do inglês Max Beerbohm (2012), contemporâneo de Oscar Wilde, $O$ farsante feliz. A personagem principal, Lord George Hell, era um farsante antipático e odioso. Em suma, um sujeito muito difícil de lidar. Nunca se preocupou em dissimular sua deslealdade, cheio de amantes, madrugadas de luxúria e jogatina. Uma noite se defronta com a desajeitada jovem Jenny Mere em um clube noturno e se apaixona perdidamente à primeira vista. Ele a pede quase que imediatamente em casamento, mas ela o recusa dizendo que só se casaria com um homem que tivesse o rosto de um santo. Ele então vai à procura de um fabricante de máscaras e lhe pede uma que represente tanto o verdadeiro amor quanto a face de um santo. 0 fabricante lhe oferece uma máscara especial que havia pertencido a um homem casado por mais de trinta anos. Lord George fica com ela e decide usá-la para sempre. Assim, munido da máscara, finalmente conquista o amor de Jenny Mere.

Depois disso, usando permanentemente a máscara, procura uma casa no bosque, devolve os bens que ganhou ilicitamente e tenta se redimir de seu passado. O único problema comparecia com os beijos que se tornavam insípidos através da máscara. Por isso, muitas vezes, apesar de temeroso pensava em retirar a máscara e beijar sua jovem esposa, por não querer manter essa barreira entre os dois. Entretanto, logo em seguida caía em si e resignava-se a ter que estar 
aprisionado à máscara enquanto vivesse, afinal ela era a representante do verdadeiro amor.

Há uma cena final importante que representa a ilusão necessária ao amor. Nela, uma antiga amante italiana comparece e desmascara Lord George e sua mulher. Ela declara que a máscara de sua jovem esposa é ainda melhor que a dele, na medida em que esse nunca nem sequer a questionou. Dito isso, a ex-amante avança sobre ele, arrancando-Ihe a máscara do amor. Curiosamente, o que passamos a ver por trás da máscara é seu rosto moldado tal qual a imagem da mesma. A imagem é vista por ele a partir de um reflexo nos olhos de sua mulher. Assim, para que ele possa assumir a nova imagem de si, faz-se necessário o reconhecimento de sua esposa, o consentimento do Outro. Daí por diante, o casal dá continuidade ao amor: ele de santo e ela de jovem campestre.

Tais exemplos servem para vivificar o não recobrimento da falta que participa do encontro amoroso, embora em ambos os casos o truque imaginário que a vela vai necessariamente ocorrer. 0 amor estabelece esse passe de mágica que faz existir algo simbólico a partir de um impossível de se preencher, um elo que liga dois seres de fala distintos.

Podemos dizer que tal ilusão existe e persiste desde a instauração de nossa própria imagem. Retomando a questão trazida pelo advento do estádio do espelho no Seminário da Angústia, Lacan sublinha como a falta é imprescindível para que o desejo e, concomitantemente, o amor possa se estabelecer:

Nesse lugar, (...) no lugar do Outro, perfila-se uma imagem refletida de nós mesmos. Ela é autenticada pelo Outro, porém, já é problemática ou até falaciosa. Essa imagem caracteriza-se por uma falta, isto é, pelo fato de que o que é convocado ali não pode aparecer. Ela orienta e polariza o desejo, tem para ele uma função de captação. Nela, o desejo está não apenas velado, mas essencialmente relacionado com uma ausência Essa ausência é também possibilidade de presença que está em outro lugar. Tal presença comanda isso muito de perto, mas o faz de onde é inapreensível para o sujeito (Lacan, 2005/196263, p. 55).

Dessa forma, somente a partir do lugar do que não se completa na imagem que nos constitui surge a possibilidade de apelo ao Outro. Nesse lugar da falta, nesse texto, Lacan (2005/1962-63) situa o que ele chama de (- phi), sinal que indica o que irá se perfilar como objeto para nosso desejo na relação com isso do corpo que não se projeta na imagem especular produzida na construção do eu: "algo irredutível a ela (imagem) por permanecer profundamente arraigado no nível do próprio corpo, do narcisismo primário, daquilo que 
chamamos autoerotismo, de um gozo autista" (Lacan, 2005/1962-63, p. 55). Esse sinal comparece como o que anima o que virá a funcionar na relação com o outro, nos seduzindo a partir de nossa semelhança.

Retomando então nosso ponto de partida, se no amor cotidiano se compactua com esse truque de mágica, de fazer dom do ser dando ao outro o que não se tem, no caso da transferência essa metáfora amorosa não poderá jamais operar. De fato, o analista deve manterse distante da "tapeação" amorosa que comparece na transferência.

Esse Outro na análise, o perigo é que ele seja enganado. Não é a única dimensão da transferência. Mas, confessem que se há domínio em que, no discurso, a tapeação tem em algum lugar chance de ter sucesso, é certamente no amor que encontramos seu modelo. Que maneira melhor de se garantir, sobre o ponto em que nos enganamos, do que persuadir o outro da verdade do que Ihe adiantamos! Não está aí uma estrutura fundamental da dimensão do amor que a transferência nos dá ocasião de imajar? Ao persuadir o outro de que ele tem o que nos pode completar, nós nos garantimos de poder continuar a desconhecer precisamente aquilo que nos falta. O círculo da tapeação, enquanto que não nomeado, faz surgir a dimensão do amor (Lacan, 1985/1964, p. 128).

Portanto, o analista deve sustentar seu desejo no caminho distinto da ilusão do amor, não se restringindo à dimensão imaginária que a transferência, num primeiro momento, nos possibilita almejar. Por isso ele precisa manter o distanciamento de sua escuta, esquivandose do velamento que o enlace amoroso pretende. Ao contrário, ele deve visar algo fora da miragem estabelecida pela transferência. Sua escuta permite o indeterminado do puro ser, isso que não tem qualquer acesso à determinação, aquilo que sempre escapole, ou seja, o discurso do inconsciente. De tal modo, Lacan vai sublinhar outro aspecto importante da transferência: o de poder dar acesso, mesmo que de maneira enigmática, à "bela por detrás dos postigos" (Lacan, 1985/1964, p. 127). Afinal, não se deve cegar quanto ao lugar da repetição que a transferência nos oferece, pois o que se repete na insistência do inconsciente é o vazio que nos concerne.

Assim, desde o Seminário sobre a Transferência, Lacan (1992/196061) procura ilustrar a resposta adequada de um analista ao amor que Ihe é dirigido através do ato de Sócrates, o mais sábio dos homens. Isso porque Sócrates não responde iludidamente como objeto de amor às tormentosas investidas de Alcibíades no percurso do Banquete. Sua recusa é coerente com o saber que ele possui sobre o amor. Ele não pode amar precisamente porque sabe. Mas, afinal, o que saberia Sócrates quanto ao amor que o posiciona distintamente 
de um érastès ou de um érôménos? Exatamente da falácia que ocorre através da metáfora do amor.

Para realizar essa analogia Lacan se detém na trama final do Banquete, caracterizada pela entrada de Alcibíades totalmente embriagado, rompendo com o gozo dos filósofos que falam calmamente sobre o amor. Essa irrupção traz à cena a reivindicação corriqueira daquele que ama, ou seja, a de almejar ocupar para o outro o lugar de máxima heterogeneidade, do incomparável, do incomensurável de um ser em particular. Por isso, a queixa de Alcibíades consiste em que Sócrates nunca o tenha tomado como objeto amoroso apesar de todas as suas tentativas de sedução. Esse advento no decorrer do Banquete rompe com as normas da erótica homossexual grega. Nesse caso, embora sendo o mais jovem e belo, é Alcibíades quem se coloca na posição de érastès perante o filósofo. Ele foi por muito tempo érômenos na relação com Sócrates, mas comparece ao encontro, embora não sendo convidado, como o desejante.

A resposta de Sócrates o aproxima da posição do analista na medida em que ele não retribui amorosamente a Alcibíades, particularmente no plano do desejo sexual. Ele se nega a lhe dar o signo de amor, respondendo com um nada à demanda que lhe é dirigida. Precisamente é disso que se trata na regra da abstinência freudiana exposta inicialmente. Assim, a resposta lacaniana que sublinha a inédita posição do analista inaugurada por Freud frente à transferência comparece através da impossibilidade de realização da metáfora do amor nesse caso. Certamente, analisar uma pessoa não implica amá-la em retorno à demanda apresentada.

Diana Rabinovich (2007/1992) situa em Modos lógicos do amor de transferência porque Sócrates é colocado por Lacan no lugar do analista. Justamente pela inversão que este possibilita sobre a posição de Alcibíades, conseguindo que passe de amado a amante, introduzindo-Ihe a falta. É essa inversão que permite caracterizar o discurso de Alcibíades e a resposta de Sócrates desde a perspectiva da transferência.

Lacan considera que a falta de resposta socrática não se funda em temperança. Precisamente, leva ao máximo a posição de érômenos ao não dar, na medida em que não sabe o que tem. (...) Sócrates se mostra aqui usando o saber sobre sua falta, mais além de sua teoria mesma acerca do amor e sua relação com a ideia de beleza por onde se situa mais além de seu próprio ideal, na medida em que seu saber sobre a falta, ao aceitá-la, Ihe permite um acesso ao contingente de cada objeto de desejo. Neste instante, tão pouco opera como amante, mas em uma posição terceira. Essa posição terceira é o que permite 
situá-lo na posição de analista (Rabinovich, 2007/1992, p. 108).

Todavia, devemos demarcar uma diferença singular designada por Lacan entre a posição de Sócrates e a do analista: a questão do pagamento em uma análise. Essa é uma diferença fundamental, ilustrativa, que acentua a recusa em realizar a metáfora do amor, operando em uma dimensão que supera o dar o que não se tem. 0 analista cobra e, no ponto em que ele o faz, recebe de seu analisando o que ele tem.

No documentário Um encontro com Lacan (2011), de Gérard Miller, isso se torna muito visível. Lilian Mahjoub, ao falar acerca das entrevistas preliminares com Lacan, lembra de como, em seu primeiro encontro, Lacan the pede tudo o que ela tivesse em sua bolsa, todo o seu dinheiro, quase como um assalto. Ela assim o faz. Quando o recebe, Lacan joga o dinheiro displicentemente sobre sua escrivaninha como se nada significasse. A partir do segundo encontro ele tende a repetir o mesmo gesto. Diante desse ato ela responde dizendo ser ele o analista certo para sua análise, mas que ela não poderia, entretanto, Ihe dar tudo o que ele pedia. Ele replica, simplesmente, que ela the desse o que lhe fosse possível.

\section{Considerações finais}

Para concluir, podemos dizer que a psicanálise está desde seu princípio emaranhada no problema da metáfora de amor em sua clínica. Freud, por não se confundir com a posição que lhe é oferecida na transferência como objeto de amor, por saber, pode inaugurar esse inédito enlace, fundando a psicanálise. Enlace que sustenta um percurso para o amor, sabendo com a transferência de onde ele parte, mas sem garantias quanto ao lugar que seu desejo o levará (Freud, 1976/1893-1895).

Torna-se necessário acrescentar que, quando a psicanálise demarca a limitação do amor, não se trata de tentar denegri-lo ou rebaixá-lo em sua função de enlaçamento. Muito ao contrário. Diante disso, ele permanece como uma construção valorosa e possível entre os seres de fala. Entretanto, será tal designação que permitirá não esperar do amor a realização do impossível, alimentando uma expectativa para além de sua capacidade. Ao comparecer como intrinsecamente limitado, o amor pode cessar a miragem de completude e permitir inventar e escrever a poesia que melhor lhe concernir. Isso é o que deve nos possibilitar uma análise.

Sendo assim, a nova posição do analista frente ao amor propicia outro lidar com esse. Ela não consiste em uma resposta afetuosa à demanda amorosa como retribuição, mas, precisamente, ao sustentar 
a existência da falta com sua resposta ímpar, permite sublinhar a hiância que nos consiste, abrindo espaço para o vazio que nos permeia. Porém, um vazio a ser entendido não como um desencontro que deve ser extirpado, mas como uma possibilidade de novas invenções e de diferentes enlaces. Um arranjo possível diante do que não se estabelece e nunca se estabelecerá. Uma linha cingida para a entrelinha de nosso dizer ou, mais precisamente, um (des)encontro.

\section{Referências}

Augustine. (2012) [film]. Directed by A. Winocour. França: France 3. Beerbohm, M. (2012). El farsante feliz: Um cuento de hadas para homebres cansados. Barcelona: Acantilado Editorial.

Dafunchio, N. S. (2011). Nudos del amor. Buenos Aires: Del Bucle.

Freud, S. (1969). Observações sobre o amor transferencial. In Edição Standard Brasileira das Obras Psicológicas Completas de Sigmund Freud (Vol 12). Rio de Janeiro: Imago. (Obra original publicada em 1915)

Freud, S. (1976). Estudos sobre a histeria. In Edição Standard Brasileira das Obras Psicológicas Completas de Sigmund Freud (Vol. 2). Rio de Janeiro: Imago. (Obra original publicada em 1893-1895)

Freud, S. (1976). Recomendações aos médicos que exercem a psicanálise. In Edição Standard Brasileira das Obras Psicológicas Completas de Sigmund Freud (Vol. 12). Rio de janeiro: Imago. (Obra original publicada em 1912)

Freud, S. (1976). Sobre o início do tratamento. In Edição Standard Brasileira das Obras Psicológicas Completas de Sigmund Freud (Vol. 12). Rio de Janeiro: Imago. (Obra original publicada em 1913)

Lacan, J. (1985). O Seminário, livro 11: os quatro conceitos fundamentais da psicanálise. Rio de Janeiro: Jorge Zahar Ed. (Obra original publicada em 1964)

Lacan, J. (1986). O Seminário, livro 1: os escritos técnicos de Freud. Rio de Janeiro: Jorge Zahar. (Obra original publicada em 195354)

Lacan, J. (1992). O Seminário, livro 8: a transferência. Rio de Janeiro: Jorge Zahar Ed. (Obra original publicada em 1960-61)

Lacan, J. (2005). O Seminário, livro 10: a angústia. Rio de Janeiro: Jorge Zahar Ed. (Obra original publicada em 1962-63)

Miller, J.-A. (2009). Logicas de la vida amorosa. Buenos Aires: Ediciones Manantial SRL.

Platão. (1983). O Banquete. In Platão, Diálogos, I. [Coleção os Pensadores]. São Paulo: Abril Cultural. 
Rabinovich, D. S. (2007). Modos lógicos del amor de transferência. Buenos Aires: Ediciones Manantial SRL. (Obra original publicada em 1992)

Um encontro com Lacan. (2011) [documentary]. Directed by G. Miller. França.

Um método perigoso. (2011) [film]. Directed by D. Cronenberg. Canadá, Reino Unido e Alemanha: Sony Pictures Classics.

\section{Endereço para correspondência}

\section{Simone Ravizzini}

Av. Almirante Ary Parreiras, 504/701, Icaraí, CEP 24230-322, Niterói - RJ, Brasil

Endereço eletrônico: simoneravizzini@gmail.com

Paulo Eduardo Viana Vidal

Rua Tupis 292, São Francisco, CEP 24360-400, Niterói - RJ, Brasil

Endereço eletrônico: paulovidal@id.uff.br

Recebido em: 17/03/2019

Reformulado em: 02/07/2019

Aceito em: 03/07/2019

\section{Notas}

* Psicanalista clínica.

** Professor Associado na Universidade Federal Fluminense.

Este artigo de revista Estudos e Pesquisas em Psicologia é licenciado sob uma Licença Creative Commons Atribuição-Não Comercial 3.0 Não Adaptada. 